\title{
Thesis Prolfiles
}

Stewart, Alistair (2012). Uncharted waters: An outdoor environmental education rhizocurrere

Ph.D

\begin{abstract}
:
This research is a curriculum autobiography that maps my attempts to develop and promote Australian outdoor environmental education practices that are inclusive of, and responsive to, the places in which they are performed. In this thesis I (re) consider the interrelated concepts, contexts and complex conversations (with colleagues, students and others) that have shaped my approach to curriculum, pedagogy and research during the past ten years. This thesis emphasises the complexity of developing curricula that engage, in a respectful and generative way, with the natural and cultural history of the Australian continent.
\end{abstract}

\section{Supervisors:}

Professor Noel Gough,

Associate Professor Andrew Brookes

La Trobe University

Contact email: a.stewart@latrobe.edu.au
Hobbs, Dale (2007). Extended stay outdoor education school program: An action research study.

Masters

\begin{abstract}
:
This study established a rationale that takes into consideration the criteria needed to establish an Extended Stay Outdoor Education School Program (ESOESP) for adolescent year nine boys. This study employed an organisational action research approach in order to develop a conceptual model of an ESOESP. The study drew upon the background, interests and values of key school stakeholders at Prince Alfred College, an independent, all boys' school located in Adelaide, South Australia. Three key stakeholder groups comprising a Senior School Management Team, Pastoral Care Team and a Curriculum Leadership Team participated in focus group discussions. Critical questions and issues generated from the three key stakeholder focus group interviews were then applied to a case study of an existing ESOESP run by a school that shares many similar characteristics with Prince Alfred College.
\end{abstract}

\section{Supervisors:}

Dr Brian Wattchow

Dr Justen O'Connor

Monash University

Contact email: dhobbs@pac.edu.au

\section{Call for recently completed Master's and Ph.D's}

We would like to profile Master's and Doctoral theses that have been completed in the area of Outdoor Education in Australasia. This is an opportunity to profile outdoor education research. It is also a valuable resource to researchers, students and practitioners in outdoor education.

If you have graduated with a Master's or Ph.D since 2005 you are invited to submit the following information:

Author

Title

Year of graduation

100 word synopsis of your thesis

Supervisor/s

Institution which awarded your degree

Address of electronic file of thesis (if available)

Contact email:

Please forward this information to Robyn Zink at ajoe@outdoorcouncil.asn.au 